\title{
Grzegorz Maroń
}

Uniwersytet Rzeszowski

\section{PUBLICZNE PROTESTY ANTYABORCYJNE W ŚWIETLE ORZECZNICTWA SĄDÓW KANADYJSKICH}

\section{WSTĘP}

Kanada posiada jedno z najbardziej liberalnych praw w odniesieniu do aborcji. Do dnia porodu kobieta może z jakiejkolwiek przyczyny zdecydować o usunięciu ciąży. Ten stan prawny jest następstwem orzeczenia Sądu Najwyższego z dnia 28 stycznia 1988 r. w sprawie R. v. Morgentaler ${ }^{1}$. Niniejszym wyrokiem sąd uchylił jako niekonstytucyjny art. 251 kodeksu karnego, który penalizował aborcję. Ustawa karna zastrzegała za aborcję karę maksymalnie dożywotniego pozbawienia wolności, a dla kobiety ciężarnej karę do dwóch lat pozbawienia wolności. Przerwanie ciąży było dopuszczalne tylko w przypadku zagrożenia życia lub zdrowia kobiety ciężarnej. Zgodę na zabieg w szpitalu wydawała komisja trzech lekarzy.

W ocenie sądu art. 251 ustawy karnej naruszał prawo kobiety do bezpieczeństwa - gwarantowane art. 7 Kanadyjskiej Karty Praw i Wolności ${ }^{2}$ - poprzez ingerencję w integralność cielesną kobiety w sensie fizycznym i psychoemocjonalnym. Sąd zakwestionował też dotychczasową procedurę uzyskiwania zgody na aborcję, uznając ją za sprzeczną z zasadami sprawiedliwości i racjonalności. Zauważył, iż jakkolwiek

\footnotetext{
$1 \quad$ R. v. Morgentaler, [1988] 1 SCR 30.

2 Canadian Charter of Rights and Freedoms. The Constitution Act, 1982, Schedule B to the Canada Act 1982 (UK), 1982, c 11 (dalej jako: Karta).
} 
państwo może mieć pewien interes w ochronie płodu na pewnym etapie ciąży to jednak art. 251 narusza prawo kobiety do bezpieczeństwa w stopniu większym niż to konieczne do zrealizowania tego potencjalnego celu.

Pełna legalizacja aborcji mocą wyroku Sądu Najwyższego doprowadziła do fali antyaborcyjnych protestów przed powstającymi klinikami aborcyjnymi (tzw. akcja Operation Rescue). Do połowy lat 90. XX w. protesty te nie zawsze miały charakter pokojowy. Towarzyszyły im niekiedy np. próby blokowania dostępu do klinik, akty wandalizmu czy bezprawne wchodzenie na teren klinik ${ }^{3}$.

Poszczególne kliniki aborcyjne zaczęły uzyskiwać sądowe nakazy (injunction) zakazujące protestów - także tych pokojowych - w ich sąsiedztwie. Do reglamentacji aktywności środowisk pro-life służą także różne przepisy prawa karnego ${ }^{4}$ oraz prawa deliktów, np. delikt bezprawnego wejścia na cudzą nieruchomość lub jej nieopuszczenia pomimo wezwania (trespass ${ }^{5}$ ), delikt niedozwolonych immisji (nuisance, np. głośne krzyczenie). Parlament Prowincji Brytyjska Kolumbia uchwalił natomiast ustawę o dostępie do świadczeń aborcyjnych zakazującą wszelkich protestów antyaborcyjnych wokół klinik aborcyjnych oraz gabinetów i miejsc zamieszkania lekarzy aborterów.

Celem opracowania jest aproksymacja oraz ocena kanadyjskiego orzecznictwa w przedmiocie publicznych protestów pro-life. Krytyczne studium wyroków sądowych pozwoli ustalić, na ile reglamentacja

3 O współczesnym aktywizmie pro-life w Kanadzie por. P. Saurette, K. Gordon, Arguing Abortion: The New Anti-Abortion Discourse in Canada, "Canadian Journal of Political Science» 46.1/2013, s. 157-185.

4 Por. np. art. 423 k.k., który przewiduje karę do 5 lat pozbawienia wolności za bezprawne zmuszanie innej osoby do określonego działania czy zaniechania poprzez m.in. używanie przemocy czy groźby przemocy; zastraszanie groźbami przemocy, innej krzywdy lub kary; uporczywe śledzenie innej osoby; blokowanie czy śledzenie miejsca, gdzie inna osoba mieszka, pracuje, prowadzi działalność czy przebywa; blokowanie drogi; śledzenie innej osoby na drodze poprzez podążanie za nią. Criminal Code, RSC 1985, c C-46.

5 Por. np. Elizabeth Bagshaw Society v. Breton, (1997) 2135 (BC SC). Sąd Najwyższy Brytyjskiej Kolumbii wyrokiem z 31 października 1997 r. uznał uczestników biernego blokowania wejścia do kliniki aborcyjnej w Vancouver winnymi trespass i zasądził od nich 20 tys. dolarów odszkodowania. 
możliwości manifestowania poglądów antyaborcyjnych pozostaje w zgodzie z podstawowymi prawami człowieka, zwłaszcza z wolnością słowa. Artykuł ukazuje kluczową rolę praktyki stosowania prawa dla określenia ram dyskursu aborcyjnego w Kanadzie. Autor, przyjmując za szkołą realizmu prawnego, że porządek prawny danego państwa jest determinowany przede wszystkim praktyką jurysdykcyjną (law in action), koncentruje się na działalności orzeczniczej sądów kanadyjskich jako najbardziej reprezentatywnego wyznacznika prawnych standardów protestów pro-life.

W pierwszej kolejności przybliżono rozumienie wolności słowa na gruncie orzecznictwa Sądu Najwyższego Kanady. Następnie przedstawiono główne założenia ustawy o dostępie do świadczeń aborcyjnych i jej aplikację do poszczególnych spraw. Omówiono także specyfikę sądowych nakazów jako narzędzia ograniczania protestów pro-life. Analizie poddano również praktykę orzeczniczą w odniesieniu do protestów antyaborcyjnych organizowanych poza sąsiedztwem klinik aborcyjnych (ulice, chodniki, place; kampusy uczelni; terminale lotnisk). W dalszej części poczyniono aproksymację argumentacji działaczy pro-life w obronie prawa do protestowania wykraczającą poza argument $\mathrm{z}$ wolności słowa (prawo dzieci poczętych do życia, prawa Boże, wolność sumienia i religii). Ukazano różne możliwe konsekwencje zawodowe związane $\mathrm{z}$ angażowaniem się $\mathrm{w}$ działalność pro-life. W końcu zasygnalizowano nieoczywistą rolę kanadyjskich sądów w debacie aborcyjnej (arbiter lub uczestnik tej debaty).

\section{WolnośĆ SŁowa W ORZECZNiCTWIE SĄDU NaJWyższego KANADY}

Art. 2 pkt b Kanadyjskiej Karty Praw i Wolności gwarantuje „wolność myśli, przekonań, opinii i słowa, włącznie z wolnością prasy i innych środków komunikacji”. Wolność słowa jest postrzegana jako jedno z fundamentalnych praw człowieka. „Trudno sobie wyobrazić bardziej 
doniosłe prawo w demokratycznym społeczeństwie niż wolność słowa"6. Wolność ta gwarantuje każdemu możliwość „manifestowania swoich poglądów, opinii, przekonań, w zasadzie wszelkich ekspresji serca i umysłu, bez względu na ich niepopularność, niesmaczność czy sprzeczność z mainstreamem. Taka ochrona jest (...) «fundamentalna», ponieważ w wolnym, pluralistycznym i demokratycznym społeczeństwie cenimy różnorodność idei i opinii ze względu na ich nieodłączną wartość tak dla wspólnoty, jak i jednostki"7. Przedmiotowa wolność legitymuje do „przekazywania naszych myśli i uczuć pokojowymi metodami bez obawy o cenzurę"8.

Wolność słowa jest nie tylko warunkiem własnej ekspresji, ale także narzędziem partycypowania w debacie publicznej i środkiem perswazji. „Kluczowe wartości, które promuje wolność słowa, obejmują samorealizację, udział w podejmowaniu decyzji społecznych i politycznych, wymianę idei we wspólnocie. Wolność słowa chroni ludzką godność i prawo do swobodnego myślenia i zastanawiania się na własnych warunkach. Umożliwia osobie mówienie nie tylko dla mówienia samego, ale również dla przekonywania do zmiany, próbowania przekonania innych w nadziei na poprawę czyjegoś życia czy być może szerszego społecznego, politycznego i ekonomicznego środowiska"9.

Podobnie jak inne prawa i wolności, także wolność słowa nie ma charakteru absolutnego. Zgodnie $\mathrm{z}$ art. 1 Karty poszczególne prawa i wolności mogą być poddawane „racjonalnym ograniczeniom, przewidzianym przez prawo, wyraźnie uzasadnionym $\mathrm{w}$ wolnym i demokratycznym społeczeństwie".

W przypadku podniesienia zarzutu pogwałcenia wolności słowa sąd, po pierwsze, weryfikuje, czy reglamentowana aktywność w ogóle mieści się w sferze chronionej wolnością słowa, tj. czy komunikuje lub próbuje komunikować pewne znaczenie ${ }^{10}$. Kanadyjskie orzecznictwo przyznaje

\footnotetext{
6 Edmonton Journal v. Alberta (Attorney General), [1989] 2 S.C.R. 1326.

7 Irwin Toy Ltd. v. Quebec (Attorney General), [1989] 1 S.C.R. 927 (968-969).

8 Ibidem (971).

9 R.W.D.S.U., Local 558 v. Pepsi-Cola Canada Beverages (West) Ltd., 2002 SCC 8 (CanLII) (32).

10 Libman v. Quebec (Attorney General), [1997] 3 S.C.R. 569.
} 
wolności słowa teoretycznie bardzo szerokie ramy, obejmując nią różne formy ekspresji. Z zakresu wolności słowa wykluczone są nieliczne wypowiedzi i często nie w sposób bezwzględny (np. nawoływanie do przemocy, kłamstwo, mowa nienawiści). Skonstatowanie, że wolność słowa znajduje in concreto zastosowanie, każe następnie rozważyć, czy poddawane ocenie przepisy poprzez swój cel lub skutek swego obowiązywania ograniczają wolność słowa. Udzielenie odpowiedzi pozytywnej prowadzi do kilkuelementowego testu konstytucyjności kwestionowanych przepisów:

1) czy przepisy ograniczające wolność słowa (lub inne prawo czy wolność) służą realizacji „dostatecznie doniosłego” celu powiązanego $\mathrm{z}$,istotnymi i naglącymi” kwestiami?

2) czy zastosowane przez prawodawcę środki są racjonalnie i wyraźnie uzasadnione (test proporcjonalności)?

Ciężar dowodu, że kontrolowana regulacja spełnia oba podstawowe wymogi, spoczywa na państwie. Sąd nie może, opierając się na powadze i autorytecie władzy czy swojej własnej intuicji, domniemywać konstytucyjności kwestionowanych przepisów. Zaliczenie testu proporcjonalności wymaga jednoczesnego spełnienia trzech poniższych warunków:

a) Użyte środki są racjonalnie powiązane ze stojącym u ich podstaw celem. Nie mogą być arbitralne, niesprawiedliwe czy oparte o irracjonalne rozważania.

b) Zastosowane środki ograniczają wolność czy prawo człowieka $\mathrm{w}$ stopniu najmniejszym z możliwych.

c) Zachodzi proporcjonalność pomiędzy skutkami zastosowania tych środków a zakładanym celem reglamentacyjnej regulacji (proporcjonalność sensu stricto) ${ }^{11}$. W drodze rachunku zysków i strat ustala się, czy korzyści z tytułu obowiązywania danych przepisów przewyższają ujemne następstwa związane z ograniczeniem konkretnego prawa czy wolności człowieka.

W pierwszej kolejności należy udowodnić, że użyte środki są zdolne przyczynić się do osiągnięcia obranego celu. Wymóg posłużenia się środkiem minimalnie naruszającym prawo lub wolność jednostki nie jest absolutny. Sąd Najwyższy dopuszcza przypadki, gdy ustawodawca nie sięga

${ }^{11}$ R. v. Oakes, [1986] 1 S.C.R. 103, 1986 CanLII 46 (SCC), (70). 
do bezwzględnie najmniej inwazyjnego środka skutecznego do osiągnięcia zakładanego celu ${ }^{12}$. Jednocześnie sąd ten wskazuje na prawidłowość, że czym cel szerzej i ogólniej ujęty, tym trudniej wykazać, że środki użyte do jego realizacji ograniczają prawo podmiotowe minimalnie ${ }^{13}$. W kontekście proporcjonalności sensu stricto Sąd Najwyższy przestrzega, że „Nawet jeśli cel jest dostatecznej doniosłości, a dwa pierwsze elementy testu proporcjonalności są spełnione, wciąż jest możliwe, że ze względu na surowość szkodliwych skutków, jakie środek wywiera na jednostki czy grupy, środek ten nie zostanie uzasadniony celami, którym miał służyć. Czym bardziej szkodliwe skutki środka, tym bardziej doniosły musi być cel, aby środek był racjonalnie i wyraźnie uzasadniony w wolnym i demokratycznym społeczeństwie"14. Należy poddać ocenie praktyczny wpływ rodzącego obiekcje prawa, ustalić jakie korzyści ono przynosi w sensie kolektywnego dobra, a zarazem jak doniosłe jest ograniczenie jednostkowych praw i wolności. W drodze wyważenia (balancing) sąd decyduje, którym racjom dać pierwszeństwo ${ }^{15}$.

Sąd Najwyższy nie wszystkim rodzajom wypowiedzi przyznaje jednakową ochronę. Zależy ona od doniosłości wartości stojących u podstaw tych wypowiedzi. Czym niższej wartości mowa, tym łatwiej uzasadnić jej ograniczenie na gruncie art. 1 Karty. Wątpliwa wartość pornografii czy mowy nienawiści uzasadnia wyłączenie ich z zakresu chronionej wolności słowa lub istotne zawężenie tej ochrony ${ }^{16}$. Wysokiej wartości jest natomiast ta mowa, która służy „poszukiwaniu politycznej, artystycznej czy naukowej prawdy, ochronie indywidualnej autonomii i samorozwoju, promowaniu udziału społeczeństwa w procesie demokratycznym”" Szczególnej ochrony wymaga „mowa polityczna, znajdująca się w sercu wolności słowa"18.

\footnotetext{
R. v. Chaulk, [1990] 3 S.C.R. 1303.

RJR-MacDonald Inc. v. Canada (Attorney General) [1995] 3 S.C.R. 199.

R. v. Oakes, (71).

Canada (Attorney General) v. JTI-Macdonald Corp., [2007] 2 SCR 610.

Regina v. Keegstra, [1990] 3 S.C.R. 697; Regina v. Butler, [1992] 1 S.C.R. 452 (500).

Ross v. New Brunswick School District No. 15 [1996] 1 SCR 825, 1996 CanLII 237

18 R. v. Guignard, [2002] 1 S.C.R. 472, 2002 SCC 14 (CanLII) (20).
}

(SCC) (89). 
Wolność słowa obejmuje także „obraźliwe uwagi i wyrazy niechęci”19. Spod ochrony art. 2 pkt b Karty nie są też wyjęte wszystkie wypowiedzi kłamliwe. Po pierwsze, „przesada - nawet jawna falsyfikacja - może służyć użytecznym społecznym celom powiązanym $\mathrm{z}$ wartościami stojącymi u podstaw wolności słowa" ${ }^{\text {"20 }}$. Po drugie, trudno ustalić znaczenie niektórych wypowiedzi, a przez to uznać je za kłamstwo lub prawdę, zwłaszcza gdy dotyczą złożonych kwestii społecznych i historycznych. Tę samą wypowiedź można interpretować na różne sposoby, np. dosłownie, $\mathrm{w}$ sensie metaforycznym czy alegorycznym. Znaczenie jest w dużym stopniu ,interaktywnym procesem zależnym i od słuchającego, i od mówiącego”, a „zdanie, które jest prawdziwe na jednym poziomie czy dla jednej osoby, może być fałszywe na innym poziomie dla innej osoby"21.

Kanadyjskie sądy, sięgając do orzecznictwa USA, przyjmują, że realizacja wolności słowa wymaga uszanowania także praw słuchaczy i widzów. Jednostka ma „prawo do wyrażania swych poglądów wobec tych, którzy chcą słuchać, ale nie posiada prawa do narzucania swojej wiadomości publiczności pozbawionej możliwości odmówienia przyjęcia tej wiadomości"22. Czynienie użytku z wolności słowa niekiedy może w drodze wyjątku doznać zatem ograniczenia, ilekroć odbiorcy komunikatu mieliby znaleźć się w pozycji „zakładników” (capitive audience).

\section{PROTESTY PRO-LIFE PRZED KLINIKAMI ABORCYJNYMI W ŚWIETLE ZASADY WOLNOŚCI SŁOWA}

3.1. Ustawa o dostępie do świadczeń aborcyjnych i jej konstytucyjność

Uchwalona przez parlament Brytyjskiej Kolumbii 19 stycznia 1995 r. ustawa (Access to Abortion Services Act) tworzy tzw. strefy dostępu (access zone) wokół klinik aborcyjnych, gabinetów lekarzy aborterów oraz

\footnotetext{
19 Saskatchewan (Human Rights Commission) v. Whatcott [2013] 1 S.C.R. 467, 2013 SCC 11 (CanLII) (39).

20 R. v. Zundel, [1992] 2 SCR 731.

21 Ibidem.

22 Lehman v. City of Shaker Heights, 418 U.S. 298, 306-7 (1974).
} 
miejsc zamieszkania tych lekarzy. W ich obrębie zakazano jakichkolwiek protestów antyaborcyjnych. Ex lege strefy takie obejmują obszar $160 \mathrm{~m}$ od granic nieruchomości, na której jest położony dom lekarza abortera, oraz $10 \mathrm{~m}$ od granic nieruchomości, na której znajduje się gabinet lekarza abortera $^{23}$. Ustawa upoważnia Gubernatora Porucznika do ustanowienia strefy dostępu dla konkretnej kliniki aborcyjnej o wielkości do $50 \mathrm{~m}$ od granic nieruchomości, na której klinika jest położona, oraz do utworzenia takiej strefy o wielkości 160 m wokół nieruchomości, na której jest położony dom dostawcy świadczeń aborcyjnych.

Przebywając w strefie, nie można „angażować się w przeszkadzanie na chodniku” (sidewalk interference) „protestować” (protest), „nękać” (beset) oraz fizycznie przeszkadzać i zastraszać pacjenta, lekarza abortera i dostawcę świadczeń aborcyjnych. O represyjności ograniczenia wolności słowa działaczy pro-life w strefie dostępu świadczą ustawowe definicje powyższych terminów. „Protestowanie” obejmuje „,jakikolwiek akt dezaprobaty lub próby dezaprobaty, dotyczący kwestii powiązanych ze świadczeniami aborcyjnymi”. „Przeszkadzanie na chodniku” oznacza doradzanie lub przekonywanie innej osoby do powstrzymania się od skorzystania ze świadczeń aborcyjnych albo też informowanie jej o kwestiach związanych z tymi świadczeniami. Oba czyny można popełnić ,jakimikolwiek środkami, w tym środkami graficznymi, werbalnymi czy tekstowymi”. „Nękania” dopuszcza się z kolei ten, kto w celu skłonienia dostawcy świadczeń aborcyjnych lub lekarza abortera do zaprzestania oferowania czy wykonywania aborcji albo przekonania pacjenta do nieskorzystania $\mathrm{z}$ aborcji, $\mathrm{w}$ sposób ciągły lub powtarzający się obserwuje go, budynek w którym on mieszka lub budynek, w którym przeprowadzane są aborcje, ewentualnie zbliża się do tej osoby i nagabuje ją (art. 2 ust 1).

Ustawa zakazuje ponadto fotografowania, nagrywania oraz $\mathrm{w}$ inny sposób graficznego utrwalania znajdujących się w strefie dostępu dostawcy świadczeń aborcyjnych, lekarza abortera czy pacjenta w celu przekonania ich do zaprzestania świadczenia, wykonywania czy korzystania

23 Gubernator Porucznik może poszerzyć wielkość strefy do 20 m dla konkretnego budynku. 
z świadczeń aborcyjnych. Zabronione jest również ponawiane komunikowanie się z przez telefon, fax, środki elektroniczne $\mathrm{z}$ inną osobą bez jej zgody w celu odwodzenia dostawcy świadczeń aborcyjnych bądź lekarza od rozpoczęcia, względnie kontynuowania oferowania czy wykonywania aborcji.

Do poniesienia odpowiedzialności konieczna jest po stronie sprawcy wiedza o istnieniu strefy $\mathrm{w}$ danym miejscu. Za pierwsze naruszenie ustawy grozi do 5 tys. dolarów grzywny i/lub do 6 miesięcy pozbawienia wolności. Za każde kolejne naruszenie grozi grzywna od 1 do 10 tys. dolarów grzywny i/lub do roku pozbawienia wolności. Wobec skazanego można orzec też sądowy dozór kuratorski (probation order) na okres do 2 lat, mocą którego nakazuje się np. utrzymywać pokój, dobrze sprawować się, nie wchodzić do strefy dostępu. Ustawa zakresem swego obowiązywania nie obejmuje prywatnych nieruchomości w obrębie stref dostępu wokół klinik aborcyjnych.

Kilkukrotnie przedmiotem oceny kanadyjskich sądów była kwestia konstytucyjności Access to Abortion Services Act. Po raz pierwszy zarzut sprzeczności postanowień ustawy, zwłaszcza jej art. 2 ust. 1, z konstytucyjną wolnością słowa podniesiono w sprawie $R$. v. Lewis. Maurice Lewis w dniu 22 września 1995 r. przed kliniką aborcyjną w Toronto trzymał w strefie dostępu plakat $\mathrm{z}$ napisem:

„Nasza Pani z Guadalupe

Patronko Nienarodzonych

Pomóż nam powstrzymać aborcję".

Został aresztowany przez policję pod zarzutem naruszenia ustawy, konkretnie zaś jego zachowanie zakwalifikowano jako niedozwolone „protestowanie” i „przeszkadzanie na chodniku”. Sąd Prowincji Brytyjskiej Kolumbii oddalił zarzuty, uznając, iż przepisy art. 2 ust. 1 pkt a i b ustawy są niekonstytucyjne, gdyż w sposób nieuzasadniony naruszają wolność słowa, wolność religii i sumienia oraz wolność zrzeszania się oskarżonego. Sąd Najwyższy Brytyjskiej Kolumbii wyrokiem z 8 października 1996 r. uchylił jednak zaskarżone orzeczenie, przyjmując, 
że wskazane przepisy są zgodne z Kartą Praw i Wolności²4. Wyrok ten trafił do Sądu Apelacyjnego Brytyjskiej Kolumbii, który to sąd umorzył postępowanie ze względu na śmierć Lewisa.

Niniejszy sąd dopiero 12 lat później ustosunkował się do konstytucyjności ustawy, wydając 4 września 2008 r. orzeczenie w sprawie przeciwko D. Sprattowi i G. Watsonowi ${ }^{25}$. Obaj mężczyźni w dniu 17 grudnia 1998 r. w strefie dostępu przed kliniką aborcyjną w Vancuver dopuścili się, podobnie jak M. Lewis, „protestowania” oraz „przeszkadzania na chodniku” ${ }^{26}$. Watson trzymał dwa plakaty, jeden z napisem „Aborcja jest morderstwem”, a drugi o treści „Nienarodzone osoby mają prawo do życia”. Pracownikom kliniki, którzy polecili mu opuścić strefę ochroną, próbował wręczyć broszury pro-life. Jednej z pracownic powiedział, że krzywdzi kobiety oraz że aborcja zwiększa ryzyko raka piersi u kobiet. Z kolei Spratt miał w ręku drewniany krzyż oraz plakat $\mathrm{z}$ napisem „Nie zabijaj”. Pracownikom kliniki mówił o miłości Boga, przebaczeniu grzechu oraz odkupieniu.

Sąd Apelacyjny prowincji Brytyjska Kolumbia w sprawie R. v. Spratt, podobnie jak Sąd Najwyższy tej samej prowincji w sprawie R. v. Lewis, stwierdził, iż jakkolwiek ustawa o dostępie do świadczeń aborcyjnych narusza konstytucyjną wolność słowa, to jednak reglamentacja tej wolności jest legalna, czyniąc zadość wymaganiom art. 1 Karty ${ }^{27}$. Oba sądy konkluzję tę poprzedziły rozważaniami według powyżej przedstawionego schematu wypracowanego w orzecznictwie Sądu Najwyższego Kanady.

24 R. v. Lewis, 1996 CanLII 3559 (BC SC). Por. R. Albert, Protest, Proportionality, and the Politics of Privacy: Mediating the Tension Between the Right of Access to Abortion Clinics and Free Religious Expression in Canada and the United States, «Loyola Of Los Angeles International and Comparative Law Review» 27.1/2005, s. 1-62.

${ }^{25}$ R. v. Spratt, 2008 BCCA 340 (CanLII).

26 Sąd Prowincji Brytyjskiej Kolumbii wyrokiem z 8 sierpnia 2000 r. oraz Sąd Najwyższy Brytyjskiej Kolumbii wyrokiem z 5 maja 2002 r. stwierdziły naruszenie przez oskarżonych art. 2 ust. 1 ustawy o dostępie do świadczeń aborcyjnych.

27 Sąd w sprawie Lewisa uznał, iż wolność zgromadzeń to odmiana wolności słowa, a rzekome naruszenie wolności zrzeszeń jest drugorzędne wobec naruszenia wolności słowa. Mając to na uwadze sąd swoje rozważania czynił wyłącznie w odniesieniu do wolności słowa oraz wolności sumienia i religii. 
Publiczne głoszenie poglądów pro-life uznano za objęte zakresem wolności słowa. „Przekonania o znaczeniu i wartości ludzkiego życia są fundamentalne dla myśli politycznej i religijnych przekonań”, a ich komunikowanie znajduje się „w sercu wolności słowa”"28. Sąd wprost stwierdził, iż „Prawo do wyrażania sprzeciwu wobec aborcji jest konstytucyjnie chronionym prawem" 29 .

Prawo to nie jest jednak absolutne i wymaga w procesie wyważenia uwzględnienia także konkurencyjnych interesów i wartości. „Prawo do wolności słowa niesie z sobą pewną odpowiedzialność za to, co się mówi i w jaki sposób"30.

Ograniczenie mowy antyaborcyjnej posiada umocowanie w prawie. Sąd orzekł, iż ustawa o dostępie do świadczeń aborcyjnych nie jest treściowo nieokreślona $\mathrm{w}$ odniesieniu do przepisu upoważniającego Gubernatora Porucznika do ustanawiania stref dostępu wokół klinik aborcyjnych. Ustawa nie przyznaje mu arbitralnej władzy w tej materii. Gubernatora Porucznika ogranicza cel ustawy oraz dopuszczalna wielkość stref i ich lokalizacja.

Cele kontrolowanych przepisów ustalono w oparciu o preambułę ustawy, historię legislacyjną aktu oraz materiały przedłożone przez prokuraturę. Zaliczono do nich ogólnie ułatwienie równego dostępu do świadczeń aborcyjnych jako świadczeń medycznych oraz zapewnienie traktowania pacjentów i osób świadczących usługi aborcyjne z poszanowaniem ich godności i prywatności. Wskazano też w tym kontekście na zwiększenie bezpieczeństwa dla osób prowadzących kliniki aborcyjne i pracujących w nich oraz polepszenie warunków niezakłóconego świadczenia usług aborcyjnych poprzez wyeliminowanie gróźb, zastraszania i nękania pacjentek, personelu i zarządzających kliniką. Wśród „istotnych i naglących" celów ustawy wymieniono również ochronę kobiet decydujących się na aborcję przed „osobistą traumą i silnym niepokojem”, przed byciem „zasmucaną czy zdenerwowaną”, przed „groźbami fizycznymi i emocjonalnym smutkiem"31.

\footnotetext{
Spratt (26-27).

Ibidem (91).

Lewis (52).

Spratt $(70,76)$.
} 
W obu sprawach sądy doszły do wniosku, że istnieje racjonalny związek pomiędzy obowiązywaniem ustawy a realizacją jej celu, ustawa nie ogranicza wolności słowa w sposób nadmierny, a korzyści skorelowane z przestrzeganiem aktu są proporcjonalne do doniosłości celu i przewyższają ujemne następstwa w postaci ograniczenia wolności słowa. Zastrzeżeń sądu nie wzbudziła wielkość stref dostępu, ich lokalizacja oraz - co najbardziej kontrowersyjne - zakres reglamentowanych w nich zachowań.

Według sądu ulotki, plakaty i werbalizowane hasła antyaborcyjne „tworzą silną, negatywną wiadomość, która jest powiązana ze stresem wielu kobiet" ${ }^{\prime 2}$. Niechciane spotkanie kobiety udającej się do kliniki aborcyjnej z aktywistami pro life przeczy jej godności. Prowadzi ono do „zażenowania i złości”, a także, co gorsze, do „psychologicznej presji, fizycznych objawów niepokoju i stresu i ogólnie utraty idealnego stanu ciszy i odprężenia podczas usługi medycznej”33. Podobnie „chodnikowe doradztwo" skutkuje niepokojem i zmartwieniem ciężarnych kobiet oraz narusza ich prywatność oraz prywatność osób im towarzyszących ${ }^{34}$. Ustawa przejawia również responywność wobec oczekiwań pracowników klinik, którzy „są uprawnieni do miejsca pracy wolnego od nękania i ciągłego alertu bezpieczeństwa" 35 .

Obiekcje wzbudza zaaprobowanie przez sądy zakazu jakiejkolwiek aktywności pro-life $\mathrm{w}$ strefach dostępu ${ }^{36}$. Nie sposób podzielić oceny, że zabronienie pokojowych i pasywnych form protestu, np. modlitwy czy milczącego trzymania plakatu z napisem „Nasza Pani z Guadalupe, Patronko Nienarodzonych, Pomóż nam powstrzymać aborcję", spełnia wymóg minimalnego ograniczenia wolności słowa.

\footnotetext{
Lewis (105).

Ibidem (107).

34 Ibidem (108).

35 Ibidem (112).
}

36 W sprawie Lewisa sąd pierwszej instancji prawidłowo ocenił ustawę za nieproporcjonalną reglamentację wolności słowa, gdyż akt ten zakazuje bezwyjątkowo nawet pokojowych protestów. Ponadto sąd zwrócił uwagę, że skala protestów antyaborcyjnych przed klinikami w pierwszej dekadzie lat 90. uległa istotnemu zmniejszeniu, a radykalne formy protestów niemal wyeliminowano. 
Sąd przekonuje, że „Jakkolwiek ustawa obejmuje pozbawione przemocy, nawet bierne, wyrażanie dezaprobaty, to jednak dowody pokazują, że taka aktywność w świetle dobrze znanej historii gwałtownych protestów oraz ze względu na wrażliwy charakter wielu wchodzących do kliniki jest sprzeczna $z$ dobrym samopoczuciem, prywatnością i godnością tych korzystających z świadczeń kliniki”" ${ }^{37}$. Dodaje, iż niektóre plakaty i ulotki pro-life „zawierające pewną przesadę i błędne informacje (...) są często obraźliwe w tonie i w treści, i byłyby uznane za obraźliwe przez racjonalną publiczność będącą na miejscu osoby wchodzącej do kliniki po świadczenia medyczne. Będąc takimi, realnie krzywdzą kobiety, wywołując więcej stresu bezpośrednio przed procedurą [aborcji]"38. Argumentacja ta w ogóle pomija okoliczność, iż wolność słowa obejmuje także wypowiedzi obraźliwe. Wątpliwe jest ponadto implikatywne formułowanie przez sąd prawa podmiotowego do „dobrego samopoczucia” czy do „bycia niezasmucanym”. Arbitralną wydaje się być też ocena, że zachowanie Lewisa „nie stanowi przykładu wolności słowa najwyższej wartości. Aktywność ograniczona przez kwestionowane przepisy nie jest kluczowa dla podstawowych wartości”39.

Nie przekonuje rozumowanie sądu, że nie sposób łatwo rozgraniczyć pokojowych i niepokojowych form ekspresji, a w związku z tym przepisy zakazujące tylko tych drugich nie zapewniłyby skutecznej ochrony kobietom i pracownikom klinik. Chcąc zatem uchronić ich przed groźbami i fizyczną przemocą, należy w ocenie sądu zakazać aktywistom pro-life jakiejkolwiek styczności z tymi osobami. Idąc tym tokiem rozumowania, należałoby zdelegalizować wszelkie publiczne demonstracje, pikiety czy marsze, bo zawsze istnieje ryzyko, że w gronie pokojowo protestujących osób znajdzie się ktoś uciekający się do przemocy. Ustawodawca nie powinien pomagać policji w ten sposób, że do jednej kategorii zalicza pokojowych działaczy pro-life i nielicznych chuliganów pro-life.

Sądy tylko częściowo mają rację, twierdząc, że ustawa nie jest nadmiernie represyjna, gdyż nie zakazuje całkowicie aktywności antyaborcyjnej,

\footnotetext{
Lewis (130).

Ibidem (141).

Ibidem (143).
} 
a tylko w strefach dostępu. Ocena taka nie uwzględnia prawidłowości, że sąsiedztwo klinik aborcyjnych stanowi kluczowe miejsce do artykułowania antyaborcyjnych komunikatów, gdyż to w tej lokalizacji przesłanie pro-life ma największą możliwość wywarcia praktycznego wpływu.

Sądy przyjęły ponadto, że kobiety udające się do kliniki w celu usunięcia ciąży, w sąsiedztwie kliniki należy postrzegać jako „zniewoloną publiczność”. „Posługiwanie się szokiem, wywoływanie stresu i pobudzanie sumienia nie są wyłącznie negatywnej wartości i niekoniecznie trzeba do nich zniechęcać. Stanowią one często narzędzia konwersacji. Jednak należy przeciwdziałać nieproszonemu użyciu tych narzędzi wobec publiczności, która w praktyce nie ma wyboru, żadnej realnej możliwości zignorowania wiadomości, żadnych środków uniknięcia wiadomości z wyjątkiem zrezygnowania ze świadczenia medycznego" W sytuacji, gdy jednostka nie jest w stanie uciec od niechcianej wiadomości, będąc jej „zakładnikiem”, wolność słowa może zostać ograniczona, gdyż nie służy w pełni tym wartościom, które stoją u jej podstaw. „Kwestia wyboru słuchania jest szczególnej doniosłości z perspektywy słuchacza"41. W ocenie sądów kobiety wchodzące do kliniki aborcyjnej nie powinny być zakładnikami wiadomości, którą protestujący chcą im zakomunikować. Wolność słowa nie obejmuje prawa do posiadania ubezwłasnowolnionych słuchaczy. Adresatom wiadomości należy według sądów zagwarantować swobodę styczności z nią według swojego wyboru $^{42}$.

O skali represyjności ustawy o dostępie do świadczeń aborcyjnych, względnie pro-represyjnej jej interpretacji, świadczy wyrok Sądu Apelacyjnego Brytyjskiej Kolumbii z dnia 25 kwietnia 2013 r. w sprawie $R$. v. Von Dehn ${ }^{43}$, mocą którego skazano za naruszenie ustawy Cecilię Von Dehn i Donalda Spratt. W ocenie sądu oskarżeni dopuścili się przestępstwa w ten sposób, że w dniu 19 czerwca 2009 r. w strefie dostępu przed placówką aborcyjną w Vancuver nosili plakaty z napisami: „Uwaga! Możesz być aresztowany w tym miejscu na podstawie ustawy nr 48 ”

\footnotetext{
40 Ibidem (106).

41 Ibidem (138).

42 Spratt (82-84).

$43 \quad$ R. v. Von Dehn 2013 BCCA 187.
} 
oraz „Miej świadomość, że ten teren według ustawodawstwa Brytyjskiej Kolumbii jest strefą dostępu. Przeczytaj ustawę nr 48”. Rozdawali też przechodniom kopie tej ustawy. Spratt miał ponadto na ustach przyklejoną taśmę jako symbol wymuszonego milczenia. Oboje aktywistów aresztowano, a następnie uznano winnymi niedozwolonego „protestowania” i „przeszkadzania na chodniku”.

Zastrzeżenia budzą zarówno poczynione przez sąd ustalenia faktyczne, jak i prawna ocena stanu faktycznego. Sąd bezpodstawnie przyjął, iż doszło do zakłócenia ruchu przechodniów na chodniku tylko na podstawie spostrzeżenia, iż plakaty wzbudziły uwagę przechodniów. Zgodnie z ustawową definicją „protestowania” oraz „przeszkadzania na chodniku" zakazane jest m.in. informowanie czy przejawianie dezaprobaty w odniesieniu do „kwestii dotyczących świadczeń aborcyjnych”. Sąd uznał, iż zachowanie oskarżonych odpowiada tej charakterystyce i nie można go potraktować tylko jako przekazywania neutralnych informacji.

Wykładnia ustawy poczyniona przez sąd jest błędna. Dehn i Spratt wyrażali sprzeciw wobec prawa zakazującego publicznych protestów pro-life, a nie wobec prawa dotyczącego legalności samej aborcji czy wprost „świadczeń aborcyjnych”. Przewodnim tematem ich pikiety była wolność słowa, a nie prawo dzieci poczętych do życia. Zachowanie oskarżonych nie tylko nie naruszało litery prawa, ale trudno też postrzegać je jako obchodzenie prawa.

\subsection{Sądowe nakazy}

Podobne treściowo do powyższej ustawy są sądowe nakazy, które konkretnym osobom lub każdej osobie zakazują w określonym miejscu, tj. najczęściej przed kliniką czy klinikami aborcyjnymi, aktywności pro-life. Zwykle $\mathrm{z}$ wnioskiem o wydanie nakazu występuje zainteresowana klinika aborcyjna ${ }^{44}$. Wyjątkowy charakter jest udziałem nakazu sądowego wydanego 30 sierpnia 1994 r. przez Sąd Najwyższy Ontario ${ }^{45}$.

44 Por. np. Centre d'information et d'action sociale de l'Outaouais (Clinique des femmes de l'Outaouais) c. Veilleux, 2008 QCCS 2599.

45 Ontario (Attorney-General) v. Dieleman, 1994 CanLII 7509 (ON SC). Por. P. Horwitz, Anti-Abortion Protests and the Public Forum. A Comment on Ontario 
Inicjatorem i wnioskodawcą tego nakazu była Prokurator Generalny Ontario Marion Boyd. Zakazuje on nie tylko 16 pozwanym, ale także każdej innej osobie jakichkolwiek protestów antyaborcyjnych w odległości 60 stóp od dwóch klinik w Toronto i 30 stóp w przypadku trzeciej kliniki, w promieniu 25 stóp od wejścia do gabinetów wskazanych lekarzy i w promieniu 500 stóp od miejsca zamieszkania konkretnych lekarzy. Konkretnie zaś zabrania:

- pikietowania, chodnikowego doradztwa, patrolowania, angażowania się w słowny protest czy nauczanie;

- utrudniania dostępu do świadczeń aborcyjnych poprzez zastraszanie, rozmawianie z inną osobą czy zbliżenie się do niej w celu przekonania jej, aby nie wchodziła do kliniki, nie pracowała w niej, nie była pacjentem kliniki;

- przekonywania lekarzy i innych osób pracujących w klinice do zaprzestania wykonywania świadczeń aborcyjnych czy pomagania w ich wykonywaniu;

- zastraszania, rozmawiania z inną osobą czy zbliżenia się do niej w celu przeszkodzenia w świadczeniu usług aborcyjnych w klinice;

- ingerowania w ekonomiczne interesy kliniki;

- bezprawnego nakłaniania do szkodzenia interesom ekonomicznym klinik poprzez wspieranie, zachęcanie czy angażowanie się w działania obliczone na wywołanie zakłócenia, przerwania, ograniczenia usług świadczonych przez kliniki;

- śledzenia czy blokowania klinik;

- rozdawania ulotek i prezentowania plakatów;

- zakłócania porządku w inny sposób.

W promieniu 160 stóp od dwóch klinik aborcyjnych i 130 stóp od jednej z kliniki zakazano podchodzenia na odległość bliższą niż 10 stóp do innej osoby, gdy ta inna osoba jasno zakomunikowała, że nie chce otrzymywać od protestującego wiadomości. Ponadto na żądanie tej osoby należy od niej odejść na odległość co najmniej 10 stóp i zaprzestać wszelkiego porozumienia się z nią. Nakaz zabrania również bezprawnego wchodzenia na teren klinik aborcyjnych oraz prezentowania

(Attorney General) v. Dieleman, «Advocates' Quarterly» 17.3/1995, s. 466-501. 
przed czterema szpitalami napisu o treści „Rzeźnik aborcyjny posłany do więzienia"46.

Zakres reglamentowanych zachowań oraz generalne określenie adresata nakazu czyni z tego nakazu akt normatywny. Jakkolwiek kanadyjskie orzecznictwo dopuszcza generalno-abstrakcyjną postać sądowych nakazów, praktyka ich wydawania budzi obiekcje. Decyzja o reglamentacji antyaborcyjnych protestów przed klinikami powinna pochodzić od ustawodawcy. Wyrok w przedmiotowej sprawie wprowadził rozwiązania normatywne, które zgodnie z zasadami demokracji należy zarezerwować dla suwerena politycznego i jego reprezentantów w parlamencie.

Zajęcie przez Prokuratora Generalnego, a nie konkretne kliniki aborcyjne czy konkretnych lekarzy aborterów, pozycji strony w postępowaniu sądowym świadczy, że rząd prowincji Ontario jednoznacznie opowiedział się po stronie pro-choice. „Rząd Ontario przyznaje, że jest pro-choice. Zainicjowanie procedury prawdopodobnie było pod wpływem tego politycznego faktu”"47. G. Huscroft zauważa, że „Decyzja o wniesieniu sprawy skutkuje czymś więcej niż tylko obraniem strony w debacie aborcyjnej. Ona jest próbą ograniczenia praw Karty wobec tych, którzy silnie sprzeciwiają się stanowisku rządu w tej debacie, w szczególności ich wolności słowa" ${ }^{\text {"⿻ }}$.

Sąd w sprawie Dieleman uzasadnił ograniczenie wolności słowa aktywistów pro-life potrzebą ochrony prywatności kobiet dokonujących aborcji. „Kiedy pozwani i inni krzyczą, wrzeszczą, mówią do czy w inny sposób komunikują się z kobietami-pacjentkami wchodzącymi do kliniki aborcyjnej, czynią to, wiedząc, że kobiety te życzą sobie anonimowości i mogą być odstraszone od poddania się aborcji poprzez ingerencję

46 Poza tym wyjątkiem sądowy nakaz nie zabrania protestów pro-life przed szpitalami. Według sądu szpitale w przeciwieństwie do klinik aborcyjnych świadczą różne usługi medyczne, a pacjenci udają się do nich z różnych powodów. Nie sposób więc, aby protestujący mogli zidentyfikować kobiety chcące poddać się w szpitalach aborcji. Ponadto szpitale posiadają wiele wjazdów i wejść, podczas gdy do klinik aborcyjnych prowadzi zwykle jedno główne wejście zazwyczaj położone przy publicznej ulicy, co ułatwia protestującym styczność $\mathrm{z}$ adresatami ich protestu.

47 Dieleman (477).

48 G. Huscroft, Reconciling Duty and Discretion: The Attorney General in the Charter Era, «Queen's Law Journal» 34/2009, s. 773-811. 
w ich prywatność"49. Sąd przyznał pierwszeństwo prywatności kobiet ciężarnych przed wolnością słowa działaczy antyaborcyjnych pomimo tego, że protesty pro-life miały miejsce na publicznych chodnikach i ulicach.

Według sądu naruszenie prywatności jest szkodliwe dla godności kobiet, skoro „decyzja o aborcji jest sprawą głęboko osobistą”50. W wyniku pogwałcenia jej prawa do prywatności „[kobieta] cierpi obrazę i afront, niekoniecznie traumę psychiczną czy przygnębienie. A nawet jeśli ona odczuwa w rezultacie niepokój czy inne symptomy choroby psychicznej, konsekwencje te wypływają z poniżenia, jakie zostało jej zadane"51.

Sąd ostatecznie uznał, iż naruszenie prywatności mieści się w zakresie deliktu niedozwolonych immisji (nuisance). Protesty antyaborcyjne stanowią immisje, gdyż zakłócają korzystanie z usług klinik aborcyjnych, gabinetów lekarskich czy domów lekarzy aborterów.

Nakaz w ocenie sądu co prawda narusza wolność słowa i wolność zgromadzeń, ale w sposób zgodny z art. 1 Karty, gdyż służy doniosłym celom oraz spełnia powyżej omówiony test proporcjonalności. Wśród celów nakazu wymieniono w szczególności: zapewnienie dostępu do bezpiecznych świadczeń aborcyjnych, ochronę fizjologicznego i psychologicznego zdrowia kobiet, ochronę prywatności kobiet w sprawach takich, jak życie, śmierć, seksualność, własny wizerunek, relacje, rodzina, plany na przyszłość; przeciwdziałanie zbędnemu poniżaniu i zakłopotaniu kobiet; ochronę osób świadczących aborcję; ochronę prywatności lekarzy aborterów i ich rodzin.

Uzasadniając proporcjonalność nakazu, sąd zwrócił uwagę, że kobiety udające się do klinik aborcyjnych stają się poniekąd zakładnikami aktywistów pro-life protestujących przed tymi klinikami. Tymczasem „wolność słowa zakłada możliwość słuchacza do niesłuchania i odwrócenia się, jeśli taka jest jego wola. Kanadyjska Karta Praw i Wolności nie gwarantuje [mówiącemu] słuchaczy, dlatego też konstytucyjne prawo do słuchania musi obejmować korespondujące $\mathrm{z}$ nim prawo do

\footnotetext{
49 Dieleman (547).

50 Ibidem (512).

51 Ibidem (559).
} 
niesłuchania” ${ }^{2}$. Sąd koncepcji „zniewolonej publiczności” nadaje kategoryczną postać. Twierdzi, że „Wolność słowa nie obejmuje prawa do tego, aby czyjaś wiadomość została wysłuchana. Ważnym argumentem na rzecz zezwolenia ludziom na swobodne wypowiadanie się jest to, że ci, dla których wiadomość jest obraźliwa, mogą po prostu odwrócić wzrok lub odejść. Gdy nie jest to możliwe, podstawowe założenie wspierające wolność słowa poddaje się w wątpliwośćc" 53 .

Sąd nie dostrzega tego, iż doktryna „słuchacza zakładnika” powinna znajdować bardzo ograniczone zastosowanie, o ile w ogóle, w miejscach uchodzących za tradycyjne forum publicznej ekspresji, jak publiczne chodniki czy ulice. Zakazanie działaczom pro-life protestowania na publicznym chodniku przed kliniką aborcyjną z powołaniem się na koncepcję „zniewolonej publiczności” czyni wolność słowa jedynie pozorną.

Sądowe nakazy nierzadko dotyczą nie tylko konkretnych osób w nich wymienionych, ale wszystkich innych (np. „John Doe, Jane Doe and Other Persons Unknown"), pod warunkiem, iż nakaz zawiera takie postanowienie. Osobie wymienionej co do tożsamości, jak i osobie niepodanej z imienia i nazwiska za naruszenie takiego nakazu grozi w myśl art. 127 k.k. do dwóch lat pozbawienia wolności. Praktyka zastępowania nakazami sądowymi ustaw znajduje wsparcie $\mathrm{w}$ orzecznictwie Sądu Najwyższego. „Kanadyjskie sądy przez dekady stosowały praktykę wydawania nakazów zakazujących ingerowania w prawo własności prywatnej, które to nakazy odnosiły się nie tylko do stron postępowania, ale również ogółu społeczeństwa" ${ }^{34}$.

Często po upływie kilkunastu lat od wydania sądowego nakazu, z założenia mającego być środkiem tymczasowym, wciąż za jego naruszenie pociągani są do odpowiedzialności aktywiści pro-life. Jako przykład można wskazać przypadki aresztowania i skazywania z art. 127 k.k. Lindy Gibbons za to, że na publicznym chodniku przed klinikami aborcyjnymi w milczeniu trzymała plakat ze zdjęciem niemowlaka i napisem

52 Ibidem (640).

53 Ibidem (641).

${ }^{54}$ MacMillan Bloedel Ltd. v. Simpson, [1996] 2 SCR 1048, 1996 CanLII 165 (SCC) 
„Mamo, dlaczego? Przecież miałem tyle miłości, aby ci dać”5 . Niniejsze zachowanie Gibbons rzekomo nawet stanowiło „zastraszanie” pacjentów kliniki poprzez wywieranie na nich „emocjonalnego wpływu” celem odwiedzenia ich od skorzystania ze świadczeń kliniki ${ }^{56}$.

\section{Protesty antyaborCyjne W INNYCH MiejSCACH NiŻ SĄSIEDZTWO KLINIK ABORCYJNYCH}

Sądy, uzasadniając konstytucyjność ustawy o dostępie do świadczeń aborcyjnych oraz wydanych przez siebie nakazów zabraniających protestowania przed klinikami aborcyjnymi, często podkreślają, iż aktywiści pro-life mogą bez przeszkód wyrażać swoje poglądy w innych miejscach publicznych. Praktyka stosowania prawa pokazuje, że argumentacja ta jest częściowo kontrfaktyczna. Reglamentacji poddawane są pokojowe protesty antyaborcyjne na publicznych chodnikach i parkingach, terenach kampusu wyższych uczelni czy lotniskach. Uczestnicy tych protestów są często zatrzymywani i aresztowani przez policję oraz stawiani w stan oskarżenia przed sądem. Nie zawsze zaś sądy opowiadają się po stronie wolności słowa.

55 R. v Gibbons, 2015 ONSC 3617 (CanLII); R. v. Gibbons, 2015 ONCA 47 (CanLII); R. v. Gibbons, [1997] O.J. No. 1811 (Prov.Div.). R. v. Gibbons, 2012 SCC 28, [2012] 2 S.C.R. 92. Ostatni z przywołanych wyroków to jedyne, jak do tej pory, orzeczenie Sądu Najwyższego Kanady odnośnie do protestów antyaborcyjnych, przy czym przedmiotem jego rozważań były wyłącznie kwestie proceduralne. Sąd orzekł, że do Lindy Gibbons znajduje zastosowanie art. 127 ust. 1 k.k., a nie przepisy postępowania cywilnego prowincji Ontario dotyczące naruszenia nakazu sądowego. Por. też kazus G. Watsona skazanego na naruszenie sądowego nakazu poprzez zwrócenie się do mężczyzny towarzyszącego kobiecie wchodzącej do kliniki aborcyjnej ze słowami: „Dopuszczasz się współudziału zabójstwa własnego dziecka, a Bóg uczyni cię odpowiedzialnym za morderstwo". R. v. Watson, 1996 CanLII 2013 (BC CA).

56 Wyższy Sąd Sprawiedliwości Ontario jako sąd odwoławczy orzeczeniem z 23 lipca 2014 r. uchylił wyrok skazujący za „zastraszanie”. R. v. Gibbons, 2014 ONSC 4269 (CanLII). 


\subsection{Kampusy uczelni wyższych}

W kanadyjskich uczelniach działają liczne organizacje czy kluby skupiające studentów podzielających wspólne wartości i cele. Wśród nich znajdują się też grupy broniące życia dzieci poczętych. Warunkiem ich aktywności na terenie uczelni jest uzyskanie formalnego uznania przez władze samorządu studenckiego. Dzięki temu grupa dla swoich różnych inicjatyw (np. spotkań, wystaw, happeningów) może bezpłatnie korzystać z infrastruktury uczelni, niekiedy też otrzymuje dofinansowanie do działalności.

Aktywność grup pro-life niejednokrotnie była reglamentowana przez samorząd studencki i władze kanadyjskich szkół wyższych, jedynie z powodu poglądów członków tych grup w przedmiocie aborcji. Przeciwdziałanie dyskryminacji studentów opowiadających się za ochroną życia dzieci poczętych utrudnia niespójność kanadyjskiego orzecznictwa. Kwestią sporną jest możliwość stosowania wobec uczelni postanowień Kanadyjskiej Karty Praw i Wolności. Przyjęcie, że Karta wiąże uniwersytety i college'e, uprawnia pokrzywdzonych studentów do powołania się w postępowaniu sądowym przeciwko uczelni na konstytucyjną wolność słowa.

Początkowo Sąd Najwyższy stał na stanowisku, że Karta nie ma zastosowania do uniwersytetów, gdyż świadczenie edukacji, jakkolwiek stanowi funkcję publiczną, to jednak nie jest częścią procesu sprawowania władzy i nie znajduje się pod kontrolą rządu ${ }^{57}$. Później jednak sąd ten uznał, że zakresem obowiązywania Karty należy objąć podmioty prywatne, jeśli w swej działalności realizują politykę czy program rządu, tak że aktywność tę można uznać za działanie władzy (act of government), chociaż dany podmiot nie wchodzi w skład aparatu władzy ani nie podlega typowemu zwierzchnictwu władzy publicznej ${ }^{58}$. Stanowisko to zostało wyrażone w kontekście sprawy prowadzonej przeciwko szpitalowi. Nie przesądza to więc, czy jest ono też aktualne w stosunku do uczelni. Sądy niższego szczebla są podzielone w tej materii.

57 McKinney v University of Guelph [1990] 3 S.C.R. 229.

58 Eldridge v British Columbia (AG), [1997] 3 SCR 624. 
Sądy prowincji Alberta dopuszczają powołanie się na Kartę przeciwko uczelniom. W jednej ze spraw Sąd Apelacyjny Alberta przyjął, że college'e i uniwersytety mogą być związane postanowieniami Karty jako podmioty egzekwujące ustawowe kompetencje władcze z wykorzystaniem środków przymusu lub jako podmioty realizujące cele władzy publicznej. W jego ocenie świadczenie edukacji wyższej jest zadaniem czy celem władzy publicznej, a wymierzanie studentom sankcji dyscyplinarnych (np. zawieszenie w prawach studenta czy wydalenie) stanowi stosowanie środków władczych ${ }^{59}$.

Stanowisko o związaniu szkół wyższych postanowieniami Karty znalazło przełożenie na sprawę dotyczącą komunikowania poglądów pro-life na Uniwersytecie w Calgary. W 2006 r. studenci zorganizowali na uczelni protest antyaborcyjny (Genocide Awareness Project). Na terenie kampusu stanęli w okręgu i trzymali plakaty porównujące aborcję do ludobójstwa. W następnym roku podczas takiego samego protestu inni studenci fizycznie zablokowali dostęp do grupy protestujących i swoimi własnymi banerami zasłonili antyaborcyjne plakaty przedstawiające zdjęcia abortowanych płodów. Władze uczelni nie interweniowały. W 2008 r. uczelnia poleciła studentom pro-life odwrócenie plakatów w czasie swojej akcji, tak aby zasłonić ich treść. Studenci odmówili, twierdząc, iż protest będzie nieefektywny, skoro ich przesłanie nie będzie widoczne dla adresatów. Uczelnia zarzuciła im dopuszczenie się deliktu nieopuszczenia terenu uczelni pomimo wezwania (trespass) oraz przewinienia dyscyplinarnego poprzez niewłaściwe zachowanie (non-academic misconduct). Pierwszy zarzut został później cofnięty. Sąd Ławy Królewskiej Alberta wyrokiem z 1 kwietnia 2014 r. nakazał władzom szkolnym rozważyć kwestię, czy zakaz możliwości prezentowania poglądów antyaborcyjnych nie narusza wolności słowa i wolności zrzeszania się studentów. Nieuwzględnienie tej kwestii w toku postępowania dyscyplinarnego było w ocenie sądu nieracjonalne ${ }^{60}$.

59 Pridgen $v$ University of Calgary, 2012 ABCA 139.

60 Wilson $v$ University of Calgary, 2014 ABQB 190. „Poczynania uniwersytetu sugerują, że preferuje studentów podejmujących fizyczne i prawdopodobnie nielegalne działania mające zakłócić niepopularne demonstracje, zamiast zezwolenia na 
Sądy prowincji Alberta oraz Sąd Ławy Królewskiej Saskachewan, powołując się na Kartę, przyznają możliwość wyrażania antyaborcyjnych poglądów na terenie należącym do szkół wyższych także osobom niebędącym studentami. Trzykrotnie uznały, iż aktywista pro-life, William Whatcott, mógł na obszarze kampusu uniwersytetów w Regina i w Calgary rozdawać ulotki antyaborcyjne czy umieszczać je za wycieraczkami zaparkowanych samochodów, prezentować plakaty antyaborcyjne czy nosić koszulki z przesłaniem pro-life. Zakazanie mu tej aktywności i aresztowanie go stanowiło naruszenie jego konstytucyjnej wolności słowa. Ostatecznie sądy uniewinniały go od zarzutów trespass, zakłócania korzystania z cudzej nieruchomości czy zaśmiecania ${ }^{61}$. W ich ocenie zachowania oskarżonego albo nie spełniały znamion zarzucanych mu czynów, albo były chronione wolnością słowa. Karta wiązała uniwersytety, gdyż uczelnie, egzekwując prawo przeciwko Whatcottowi, wykonywały zadania władzy publicznej, a nie tyle korzystały z uprawnień właściciela terenu. Podkreślono ponadto, że uczelnie powinny być platformą dla wymiany różnych idei i pogłębiania wiedzy bez cenzury i selekcji poglądów. Zwrócono uwagę na to, że szkoły wyższe są finansowane $\mathrm{z}$ publicznych pieniędzy. W końcu wskazano, że uniwersytet, ograniczając wolność słowa, ogranicza możliwości partycypowania przez mieszkańców prowincji w szeroko rozumianym procesie kształcenia, będącym zadaniem władzy.

Do innych wniosków doszły natomiast sądy w Ontario i w Brytyjskiej Kolumbii. Uniwersytet Carlton nie pozwolił w 2011 r. swoim studentom na zaprezentowanie na terenie uczelni zdjęć z przesłaniem pro-life. Sąd Apelacyjny Ontario wyrokiem z 29 czerwca 2012 r. uznał, iż do uczelni nie stosuje się Karty. W jego ocenie uczelnia, decydując o udostępnieniu swej infrastruktury do celów wykraczających poza program kształcenia, nie realizuje celów czy polityki rządu ${ }^{62}$.

\footnotetext{
wyrażanie zróżnicowanych poglądów”. F. Silletta, Revisiting Charter Application to Universities, «Appeal - Review of Current Law and Law Reform» 20/2015, s. 81.

${ }_{61}$ Por. $R v$ Whatcott, 2014 SKPC 215 (CanLII); $R v$ Whatcott, 2012 ABQB 231; R. $v$ Whatcott, 2002 SKQB 399 (CanLII).

62 Lobo v. Carleton University, 2012 ONCA 498 (CanLII).
} 
Podobnie orzekł 14 stycznia 2015 r. Sąd Najwyższy Brytyjskiej Kolumbii w sprawie Uniwersytetu Victoria. Studencka organizacja pro-life na tej uczelni nie uzyskała w 2013 r. zgody władz uniwersytetu na wykorzystanie terenu kampusu do antyaborcyjnej kampanii zwanej Choice Chain. Akcja ta polega na tym, że jej uczestnicy trzymają naprzemiennie plakaty przedstawiające zdjęcie abortowanego płodu i zdjęcia żyjącego i rozwijającego się płodu. U podstaw odmownej decyzji był sprzeciw samorządu studenckiego, przyjmującego oficjalnie stanowisko pro-aborcyjne. Pomimo braku zgody akcja odbyła się. Decyzją władz uczelni członkom organizacji pro-life udzielono upomnienia. Sąd uznał, iż udostępnianie terenu uczelni dla aktywności studenckich klubów nie jest realizowaniem polityki czy programu władzy, tak więc w przedmiotowej sprawie Karta nie znajduje zastosowania ${ }^{63}$.

Sądy w obu sprawach nie wzięły pod uwagę tego, że uczelnie są współfinansowane z podatków, a władze prowincji powołują część ich kadry kierowniczej. Ponadto pominięto okoliczność, że jedynym powodem odmowy uwzględnienia wniosku studentów pro-life była treść ich prezentacji. Uczelnie arbitralnie podejmują decyzje tego typu, co skutkuje dyskryminacją jednych poglądów i faworyzowaniem innych. Nieprzekonujący wydaje się argument, że zakaz prezentowania zdjęć abortowanych płodów jest motywowany drastycznością ich treści. Troska o komfort psychiczny przechodniów nie stanęła uniwersytetom na przeszkodzie zezwolenia sympatykom Falun Gong prezentowania zdjęć osób torturowanych przez władze chińskie czy pokazywania drastycznych zdjęć ofiar wypadków samochodowych w ramach kampanii promowania zapinania pasów bezpieczeństwa.

Kontrfaktyczna jest charakterystyka kanadyjskich uczelni jako miejsca intelektualnej wolności i różnorodności ${ }^{64}$. Trybunał Praw Człowieka Brytyjskiej Kolumbii decyzją z 16 stycznia 2008 r. nie uwzględnił skargi studenckiego klubu pro-life, któremu samorząd uczniowski Uniwersytetu Brytyjskiej Kolumbii Okanagan odmówił dalszej akredytacji ze względu na sprzeciw części studentów wobec działalności klubu. Klub

\footnotetext{
63 BC Civil Liberties Association v University of Victoria 2015 BCSC 39 (CanLII).

64 BC Civil Liberties Association v University of Victoria 2015 BCSC 39.
} 
poprzez projekcję filmu, wystawę oraz broszury przedstawiał zdjęcia abortowanych płodów, porównując aborcję z ludobójstwem na podobieństwo Holocaustu czy czystek w Kambodży i Rwandzie. Trybunał uznał, iż skarga racjonalnie nie rokuje na uwzględnienie, gdyż decyzja samorządu o odmowie uznania klubu była oparta o kryterium obraźliwości antyaborcyjnych treści rozpowszechnianych przez klub, a nie o religijne przekonania jego członków ${ }^{65}$. Samorząd uczniowski, podejmując decyzję, nie przejawiał wrogości wobec chrześcijan czy w szczególności katolików ${ }^{66}$.

Sąd Najwyższy Brytyjskiej Kolumbii orzeczeniem z 17 października 2008 r. utrzymał w mocy decyzję Trybunału ${ }^{67}$. Przyjął, iż standardem kontroli jest kryterium „oczywistej nieracjonalności”. Decyzja Trybunału nie była zaś „oczywiście nieracjonalna”. O takiej jej charakterystyce można by mówić tylko wtedy, gdyby trybunał „zaangażował się w arbitralny proces decyzyjny, wyraźne wyłączył zasadę czy kluczową kwestię ze swoich analiz oraz poczynił błędy co do stanu faktycznego tak poważne, że skutkujące arbitralną decyzją"68. Sąd uznał, iż decyzja o nie akredytacji nie wpływa istotnie na możliwość wyrażania poglądów przez klub, a jedynie pozbawia go np. możliwości dofinansowania. W ocenie sądu prezentacje pro-life były „obraźliwe w tonie i w treści” ${ }^{\prime}$. Podzielił też opinię Trybunału, że „Nie było nigdy celem ustawodawcy ustanawiającego Kodeks Praw Człowieka, aby ochrona wolności religijnej stała się mieczem, przy pomocy którego grupy religijne mogą pozyskiwać korzyści niebędące udziałem grup świeckich będących w podobnej sytuacji. Aby chronić przed takim skutkiem, jest konieczne postawić wyraźną granicę pomiędzy, z jednej strony, ochroną prawdziwych re-

65 Kluby pro-life miałyby większe szanse w sporze z uczelniami, gdyby akty prawne jako zakazane kryterium dyskryminacji wymieniały także „polityczne przekonania”. D. Mrx-Ross, Exploring the Charter's Horizons: Universities, Free Speech, and the Role of Constitutional Rights in Private Legal Relations, Toronto 2009, s. 1-3.

66 Gray and others v. University of British Columbia Students' Union - Okanagan (No. 2), 2008 B.C.H.R.T.D., No. 16, aff'd [2008] B.C.J. No. 2147.

67 Gray v. UBC Students' Union, 2008 BCSC 1530 (CanLII).

68 Ibidem (110).

69 Ibidem (27). 
ligijnych praktyk i przekonań przed dyskryminacją, a z drugiej strony zapewnieniem, że nikt nie jest zmuszany do promowania poglądów religijnych innych osób"70.

Zwraca uwagę, iż ten sam Trybunał Praw Człowieka Brytyjskiej Kolumbii dwa dni przed podjęciem powyższej decyzji w analogicznej sprawie doszedł do innych wniosków. Klub studencki pro-life w Capiano College w Vancouver nie uzyskał akredytacji samorządu studenckiego wymaganej do oficjalnej działalności na terenie uczelni. Powodem odmownej decyzji były antyaborcyjne poglądy członków klubu. Samorząd argumentował, iż jest organizacją pro-choice, pod auspicjami której nie ma miejsca dla grup antyaborcyjnych. Po wniesieniu skargi do Trybunału, w której zarzucono dyskryminację studentów pro-life ze względu na religię i po wstępnym dopuszczeniu skargi do dalszego procedowania, klub pro-life i samorząd uczniowski zawarły porozumienie, na podstawie którego klub ostatecznie uzyskał akredytację. Trybunał uznał, iż „poglądy pro-life są integralnym i głęboko zakorzenionym aspektem religijnych przekonań" studentów klubu, co uzasadnia powołanie się w skardze na dyskryminację ze względu na religię ${ }^{71}$.

Przypadki tłumienia aktywności studenckich i uczniowskich środowisk antyaborcyjnych w kanadyjskich szkołach i na uczelniach nie są odosobnione. Nowe kluby pro-life często nie uzyskują zgody na rozpoczęcie działalności, a tym dotychczas istniejącym zgoda ta jest cofana. $\mathrm{Na}$ Uniwersytecie Brytyjskiej Kolumbii samorząd studencki zakazał klubowi studenckiemu działalności na terenie kampusu po tym, jak jego członkowie wywiesili plakat o zgodnej z prawdą treści „W Kanadzie nie istnieje prawo karne przeciwko aborcji”. Samorząd studencki Uniwersytetu Thompson Rivers w Kamloops zakazał z kolei działalności klubowi pro-life w związku z akcją klubu zaprezentowania modeli płodów różnej wielkości przedstawiających poszczególne fazy rozwoju płodowego. Jeden z członków samorządu skonfiskował nawet wystawę ${ }^{72}$.

\footnotetext{
70 Ibidem (49).

71 Macapagal and others v. Capilano College Students' Union (No. 2), 2008 BCHRT 13 (19) (CanLII).

72 C. Jones, Immunizing Universities from Charter Review: Are We 'Contracting Out' Censorship?, «University of New Brunswick Law Journal» 52/2003, s. 267-268. Po
} 


\subsection{Publiczne chodniki i place oraz porty lotnicze}

Ograniczeniom są poddawane protesty pro-life także $\mathrm{w}$ miejscach uchodzących za klasyczne forum ekspresji opinii i poglądów. W dniu 10 sierpnia $2001 \mathrm{r}$. W. Whatcott przeprowadzał antyaborcyjny protest na chodniku i parkingu przy ulicznym skrzyżowaniu w Moose Jaw. On i inni demonstranci trzymali plakaty ze zdjęciami abortowanych płodów. Rozdawał też ulotki pro-life pieszym. Pomiędzy protestującymi a kierowcami dochodziło do słownych utarczek. Przybyła na miejsce policja aresztowała Whatcotta. Sąd pierwszej instancji skazał go za zakłócanie porządku poprzez krzyczenie w miejscu publicznym (art. 175 ust. 1 pkt a(i) k.k.) oraz za utrudnianie czynności służbowych policjantowi, który go zatrzymał (art. 129 ust. 1 k.k.) i wymierzył mu grzywnę.

Sąd Ławy Królewskiej wyrokiem z 30 czerwca 2005 r. uniewinnił go z obu zarzutów. Uznał, iż samo krzyczenie jako forma wyrażania poglądów nie stanowi zakłócania porządku, a zachowanie Whatcotta nie utrudniło ruchu ulicznego czy ruchu pieszych. Emocjonalne wzburzenie czy zasmucenie kierowców i przechodniów wywołane treścią przesłania Whatcotta nie wystarcza do przyjęcia popełnienia czynu $\mathrm{z}$ art. 175 ust. 1 pkt a(i) k.k.

Ten sam sąd rok wcześniej orzeczeniem z 18 października $2004 \mathrm{r}$. również uchylił wyrok skazujący Whatcotta za utrudnianie czynności służbowych policjantowi poprzez odmowę zaprzestania pokazywania kierowcom plakatów ze zdjęciami abortowanego dziecka przy ruchliwym skrzyżowaniu w mieście Prince Albert w dniu 2 lipca 2002 r. W ocenie sądu policjant kierował się nie tyle bezpieczeństwem ruchu drogowego, co treścią plakatów. W sposób nieuzasadniony została naruszona wolność słowa Whatcotta, skoro prawo chroni zarówno formę, jak i treść jego komunikatu ${ }^{73}$.

wniesieniu skargi do Komisji Praw Człowieka samorząd uczniowski wycofał się ze swojej decyzji i przywrócił klubowi pełne prawa. Por. M. WALdron, Free to Believe: Rethinking Freedom of Conscience and Religion in Canada, Toronto 2013, s. 145-150.

73 R. v. Whatcott, 2004 SKQB 413 (CanLII). Sąd pierwszej instancji uniewinnił Whatcotta od zarzutu zakłócania ruchu ulicznego (stunt). 
Zasadniczo bezskuteczne były natomiast powództwa Whatcotta bezpośrednio przeciwko funkcjonariuszom policji, którzy aresztowali go $\mathrm{w}$ związku z jego antyaborcyjnymi ulicznymi protestami oraz rozprowadzaniem ulotek pro-life do przydomowych skrzynek pocztowych ${ }^{74}$.

Sąd Prowincji Alberta wyrokiem z 15 lipca 2013 r. uniewinnił członków organizacji Centre for Bio-Ethical Reform od zarzutu trespass w związku z ich protestem antyaborcyjnym w hali przylotów lotniska w Calgary w dniu 22 października 2011 r. Protestujący rozdawali ulotki i prezentowali plakaty ze zdjęciami abortowanych płodów oraz rozmawiali z pasażerami o złu aborcji. Nie opuścili lotniska pomimo wezwań władz portu.

Sąd uznał, iż demonstranci mogą powołać się na przepis, zgodnie z którym odpowiedzialność za trespass zostaje wyłączona, gdy dana osoba działała „na podstawie uczciwego i racjonalnego założenia, że miała prawo zachować się w zarzucany jej sposób"75. Ponad dwadzieścia lat wcześniej Sąd Najwyższy przyjął, iż lotnisko (konkretnie poczekalnie, hole, foyer, sklepy, restauracje) pełni podobną funkcję, jak klasyczne miejsca publicznych protestów, tj. ulice i parki ${ }^{76}$. Wyrażanie poglądów w tych lokalizacjach służy demokratycznej debacie, poszukiwaniu prawdy i samorealizacji ${ }^{77}$.

W ocenie sądu do lotniska stosuje się Karta, a zachowania demonstrantów były chronione w ramach wolności słowa. Władze Prowincji sprawują kontrolę nad zarządcą lotniska, ewentualnie podmiot ten realizuje zadania władzy publicznej. $Z$ kolei teren lotniska stanowi własność publiczną ${ }^{78}$.

Powyższy wyrok nie przeszkodził Sądowi Ławy Królewskiej, aby orzeczeniem z 13 sierpnia 2014 r. przyznać władzom portu lotniczego w Calgary warunkowy sądowy nakaz (interlocutory injunction), obligujący członków Canadian Centre for Bio-Ethical Reform oraz każdą inną

74 Whatcott v. Prince Albert Board of Police Commissioners, 2005 SKQB 160; Whatcott v. Schluff, 2009 SKQB 56 (CanLII).

75 Trespass to Premises Act, RSA 2000, c T-7 (art. 8).

76 Committee for the Commonwealth of Canada v. Canada, [1991] 1 SCR 139.

77 Montréal (City) v. 2952-1366 Québec Inc., [2005] 3 SCR 141, 2005 SCC 62 (CanLII).

78 R. v. Booyink, 2013 ABPC 185 (CanLII). 
osobę do powstrzymania się od protestów antyaborcyjnych na terenie lotniska. Konkretnie zakazał przeszkadzania pasażerom, pracownikom $\mathrm{i}$ innym osobom $\mathrm{w}$ korzystaniu $\mathrm{z}$ lotniska poprzez rozprowadzanie ulotek, broszur, czy innych publikacji oraz poprzez prezentowanie plakatów, bilboardów, bannerów. Osoby objęte nakazem zobowiązano ponadto do opuszczenia terenu lotniska po wezwaniu przez władze lotniska. Jednocześnie sąd polecił powodowi wystąpić na drogę procesową celem finalnego ustalenia, czy Karta znajduje zastosowanie do władz lotniska i czy działania Centre for Bio-Ethical Reform są chronione wolnością słowa. Od rozstrzygnięcia tej kwestii uzależniono dalsze obowiązywanie nakazu ${ }^{79}$.

\section{Protesty ANTYABORCYJNE A WOLNOŚĆ SUMIENIA I RELIGII}

O wiele rzadziej aktywiści pro-life, broniąc swojego prawa do publicznego wyrażania sprzeciwu wobec aborcji, powołują się na wolność sumienia i religii (art. 2 pkt a Karty). Według Sądu Najwyższego wolność religii obejmuje „prawo do żywienia przyjętych religijnych przekonań, prawo do ogłaszania religijnych przekonań otwarcie, bez strachu przed przeszkodami i odwetem, prawo do manifestowania religijnych przekonań poprzez sprawowanie kultu i praktykowanie albo przez nauczanie i rozpowszechnianie" 80 . Integralnym elementem wolności religii jest zatem także przekonywanie innych do uznania wyznawanych zasad religijnych. Zarazem Sąd Najwyższy stoi na stanowisku, że „przyjmując szczerość utrzymywanego religijnego przekonania, nie jest dopuszczalne dla sądu kwestionowanie jego ważności" "81, czyli weryfikowanie, na ile konkretne przekonanie znajduje umocowanie w oficjalnej doktrynie partykularnej religii.

Powyższe rozumienie wolności religii wpłynęło na argumentację sądu w wspomnianej sprawie Lewisa. Sąd wyraźnie podkreślił, że „Wolność

79 The Calgary Airport Authority v Canadian Centre for Bio-Ethical Reform, 2014 ABQB 493 (CanLII).

$80 \quad$ R. v. Big M Drug Mart Ltd., [1985] 1 S.C.R. 295 (336).

81 Ross v. New Brunswick School District No. 15, (1996) CanLII 237 (SCC), (71). 
postępowania czy działania celem manifestowania religijnych przekonań mieści się w wolności religii”" ${ }^{2}$. Przyjął, że przepisy prawne należy poddać badaniu konstytucyjności, jeśli skutkiem ich obowiązywania jest ingerowanie $\mathrm{w}$ indywidualną religijną aktywność czy religijne przekonania. Antycypując prawdziwość religijnych przekonań Lewisa w odniesieniu do aborcji, sąd uznał je za wyłączone spod kontroli, czy są one właściwe dla wyznawanej przez oskarżonego religii. W ocenie sądu Lewis szczerze uważał, że swoim protestem wypełniał wolę Boga. Okoliczność, że „jego religia nie zmusza większości innych współwyznawców tej religii do czynienia tego samego" nie ma znaczenia. Ostatecznie sąd doszedł do wniosku, że jakkolwiek doszło do naruszenia wolności religii Lewisa, to naruszenie to było uzasadnione w rozumieniu art. 1 Karty.

Inną argumentację przyjął sąd w powyżej przywołanej sprawie Dieleman. W świetle jednak późniejszego i zasygnalizowanego orzecznictwa Sądu Najwyższego rozumowanie to nie wydaje się być reprezentatywne dla kanadyjskiego porządku prawnego. Sąd uznał się za kompetentny do badania, czy dana religia wymaga określonej formy aktywności, np. publicznych protestów lub zachęca do niej. Doszedł do wniosku, że zachowanie jednej z pozwanych, Jane Ubertino - która w każdy pierwszy piątek miesiąca spacerowała na chodniku przy klinice aborcyjnej w Toronto i milcząco modliła się przez godzinę w intencji dzieci nienarodzonych - nie mieści się w zakresie wolności religijnej. Uzasadnił to tym, że publiczna dezaprobata aborcji poprzez protestowanie czy pikietowanie przed kliniką aborcyjną nie jest podzielana przez znaczącą większość chrześcijan. W ocenie sądu religia suponuje poglądy i postępowanie pewnej grupy, gdy tymczasem postępowanie Ubertino było działaniem indywidualnym, a nie zachowaniem jako członka grupy. Sąd orzekł jednak, że działania motywowane sumieniem są o wiele szersze niż te inspirowane religią i w związku z tym zezwolił Ubertino na kontynuowanie dotychczasowej praktyki jako mieszącej się w pojęciu wolności sumienia. $\mathrm{Z}$ zakresu wolności sumienia i wolności religii wykluczył natomiast zachowania pozostałych pozwanych w sprawie. 
Stanowisko sądu, zgodnie z którym o objęciu danego zachowania wolnością religii decyduje zachowanie większości wyznawców tej religii, na którą dana osoba się powołuje, nie tylko że nie znajduje umocowania w orzecznictwie sądów wyższych instancji, ale jest merytorycznie błędne. Obranie za wzorzec kontrolny postępowania większości wiernych prowadziłoby do np. konkluzji, że uczestniczenie przez katolika w niedzielnej mszy świętej nie jest objęte wolnością religii, skoro niedzielne nabożeństwa praktykuje w Kanadzie zdecydowana mniejszość katolików.

6. PraWo DZIECI POCZĘTYCH do ŻyCia oRAZ PRAWo Boże JaKo UZASADNIENIE PROTESTÓW PRO-LIFE

Nieskuteczne są próby powoływania się na prawo podmiotowe nasciturusa do życia jako argumentu za legalnością protestów antyaborcyjnych sprzecznych z ustawą czy sądowym nakazem. Argumentację tego typu odrzucono np. w wyroku Sądu Apelacyjnego Brytyjskiej Kolumbii z 17 stycznia 2003 r. w sprawie R. v. Demers ${ }^{83}$, czy wyroku Sądu Sprawiedliwości Ontario z 12 czerwca 2014 r. w sprawie R. v. Wagner ${ }^{84}$. James Demers został 19 grudnia 1997 r. skazany przez Sąd Prowincji Brytyjskiej Kolumbii za naruszenie ustawy o dostępie do świadczeń aborcyjnych w ten sposób, że w dniach 6-10 grudnia 1996 r. stał z zasłoniętymi oczami na publicznym chodniku przed kliniką aborcyjną w Vancouver, trzymając plakat z napisem: „Każda istota ludzka ma nieodłączne prawo do życia. Międzynarodowy Pakt Praw Obywatelskich i Politycznych”. Z kolei 11 grudnia prezentował plakat o treści „Każda osoba ma prawo do poszanowania jej życia. Prawo to będzie chronione ustawą i, w zasadzie, od momentu poczęcia. Art. 4 ust. 1 Amerykańskiej Konwencji Praw Człowieka”. Nie rozmawiał z żadnym pacjentem ani pracownikiem kliniki. Nie przedstawiono dowodu, aby którykolwiek

\footnotetext{
83 R. v. Demers, [2003] B.C.C.A. 28.

${ }^{84}$ R. v. Wagner, 2015 ONCJ 66. Por. G. Maroń, Glosa do wyroku Sądu Sprawiedliwości Ontario w sprawie R. v. Wagner z dnia 12.06.2014 (R. v. Wagner, 2015 ONCJ 66), «Roczniki Nauk Prawnych» 3/2015, s. 193-216.
} 
przechodzień poczuł się obrażony czy zasmucony zachowaniem Demersa. Po zatrzymaniu Demersa przez wezwaną przez klinikę policję, działacz pro-life spędził $\mathrm{w}$ areszcie 7 tygodni, oczekując na proces ${ }^{85}$.

Z kolei Mary Wagner w dniu 15 sierpnia 2012 r. wbrew warunkom probacji weszła na teren kliniki aborcyjnej w Toronto i wręczała przebywającym tam kobietom zamierzającym usunąć ciążę róże oraz broszury pro-life. Sąd uznał ją winną zakłócenia korzystania z prywatnej własności oraz naruszania dwóch sądowych nakazów nadzoru kuratorskiego.

Sądy w obu sprawach, bazując na kanadyjskim orzecznictwie ${ }^{86}$, uznały, iż dziecko poczęte nie jest „każdym” w rozumieniu art. 7 Karty gwarantującego prawo do życia. J. Demers i M. Wagner nie mogli więc uzasadniać swoich antyaborcyjnych protestów działaniem w obronie prawa do życia nasciturusa, np. w ramach obrony koniecznej czy stanu wyższej konieczności.

Odrzucono też możliwość wyprowadzenia prawa dziecka poczętego do życia z przykazania Bożego „Nie będziesz zabijał”. W ocenie sądów preambuła Karty stanowiąca, że „Kanada opiera się na zasadach uznających zwierzchnictwo Boga i rządy prawa” nie czyni z Kanady państwa wyznaniowego, które musiałoby interpretację własnych ustaw i common law czynić zgodną z Dekalogiem.

85 Wyrok skazujący utrzymał w mocy Sąd Najwyższy Brytyjskiej Kolumbii orzeczeniem z 3 sierpnia 1999 r. R. v. Demers, [1999] 17 BCTC 117. Demers 19 marca 2004 r. wniósł przeciwko Kanadzie skargę (nr 225-04) do Między-Amerykańskiej Komisji Praw Człowieka. Komisja w raporcie nr 85/06 z 21 października 2006 r. uznała dopuszczalność skargi w odniesieniu do art. 4 Amerykańskiej Deklaracji Praw i Obowiązków Człowieka (wolność słowa i rozpowszechniania idei). Por. J. Tuomala, Petitioner's Observations (February 2007) for the Redress of Violations of Human Rights Guaranteed by The American Declaration of the Rights and Duties of Man, Inter-American Commission on Human Rights, http://digitalcommons.liberty.edu/lusol_fac_pubs/46; odczytano 26 czerwca $2015 \mathrm{r}$.

86 Borowski v. Canada (Attorney General), 1987 CanLII 4890 (SK CA) Winnipeg Child and Family Services (Northwest Area) v. D.F.G., [1997] 3 S.C.R. 925; Tremblay v. Daigle, [1989] 2 S.C.R. 530. 
7. OdPOWIEDZIALNOŚĆ DYSCYPLINARNA ZA ANGAŻOWANIE SIĘ W PROTESTY PRO-LIFE

Kazus Williama Whatcotta obrazuje próbę reglamentowania protestów antyaborcyjnych poprzez pociąganie ich uczestników do odpowiedzialności zawodowej. W. Whatcott, będący z zawodu pielęgniarzem, przez kilka dni w 2002 r. pikietował przed siedzibą proaborcyjnej organizacji Planned Parenthood w Regina. Trzymał plakaty ze zdjęciami abortowanych płodów oraz napisem „Planned Parenthood abortuje dzieci”, „Holokaust Hitlera. Holocaust Kanady”. Krzyczał też „Planned Parenthood da ci AIDS”. „To miejsce jest największym na świecie zabójcą dzieci” i „Planned Parenthood morduje niewinne dzieci”. Planned Parenthood wniosła do Stowarzyszenia Licencjonowanych Pielęgniarzy Prowincji Saskachewan (SALPN) skargę na Whatcotta, zarzucając mu naruszenie reguł zawodowych ${ }^{87}$.

Komisja Dyscyplinarna SALPN uznała Whatcotta winnym przewinienia zawodowego i ukarała go grzywną 15 tys. dolarów. Zawiesiła go też w prawach członka SALPN na $45 \mathrm{dni}$, a do czasu zapłacenia grzywny zakazała mu wykonywać zawodu. Sąd Ławy Królewskiej wyrokiem z 18 lipca 2006 r. utrzymał decyzję w mocy. Sąd Apelacyjny orzeczeniem z 16 stycznia 2008 r. uchylił jednak decyzję jako niekonstytucyjną ${ }^{88}$.

W ocenie Sądu Apelacyjnego celem i skutkiem rozstrzygnięcia SALPN było naruszenie wolności słowa Whatcotta poprzez odebranie mu prawa do pikietowania $w$ takiej formie i w taki sposób, jaki on obrał. $\mathrm{W}$ toku postępowania dyscyplinarnego w ogóle nie poddano wolności słowa Whatcotta wyważeniu z rzekomo konkurencyjnymi standardami zawodu pielęgniarza. Sąd zwrócił uwagę, iż nie ma żadnego dowodu, aby działania Whatcotta źle wpłynęły na publiczne postrzeganie zawodu

87 Dzień przed przesłuchaniem go przez SALPN Whatcott 26 sierpnia $2003 \mathrm{r}$. ponownie protestował przed budynkiem Planned Parenthood, trzymając plakaty z napisami „Boży dar życia”, „Planned Parenthood poleca aborcje”. Mówił też „Planned Parenhood deprawuje młode kobiety”, „Planned Parenthood zabija dzieci środkami chemicznymi”, „Cudzołożnicy nie odziedziczą królestwa niebieskiego”.

88 Whatcott v. Saskatchewan Association of Licensed Practical Nurses, 2008 SKCA 6 (CanLII). 
pielęgniarza. Za sprawą jego pikiety prestiż zawodu ani nie ucierpiał, ani się nie powiększył. O tym prestiżu nie decyduje to, co pielęgniarz robi w czasie wolnym, ale jak wykonuje swoje obowiązki zawodowe wobec pacjentów. Nie przedstawiono też dowodów na okoliczność, iż zakazanie Whatcottowi wykonywania zawodu przysłuży się lepszemu społecznemu wizerunkowi pielęgniarza. Ludzie obserwujący go w trakcie pikiety nie wiedzieli, że jest pielęgniarzem. On się tym w trakcie protestu nie afiszował. Whatcott działał w czasie wolnym od pracy i poza terenem szpitala, bez uszczerbku dla systemu zdrowia publicznego. Związek protestów pro-life z jego pracą jest niewielki. Nie sposób też, zdaniem sądu, wypowiedzi Whatcotta i treści jego plakatów charakteryzować jako fałszywych i zniesławiających, gdyż są one wyrazem przekonań i opinii, a nie komunikowaniem faktów.

Mniej kategoryczny w ostatniej kwestii był Sąd Ławy Królewskiej rozpoznający pozew Planned Parenthood o odszkodowanie i zakazanie Whatcottowi prezentowania przed jego siedzibą antyaborcyjnych plakatów. W wyroku z 25 lipca 2002 r. zarzut zniesławienia przekazał do dalszego rozpoznania, zakazując do tego czasu nazywania Planned Parenthood Regina miejscem zabijania, a jego pracowników zabójcami, aborcjonistami czy szerzącymi AIDS ${ }^{89}$. Sąd podniósł bowiem, że Planned Parenthood Regina wprawdzie czerpie korzyści z doradztwa aborcyjnego, ale w swoich budynkach nie przeprowadza samej aborcji. Nie podzielił natomiast zarzutu, że Whatcott dopuścił się deliktu zastraszania. Ponadto sąd zauważył, iż pikietowanie może być zakazane tylko wtedy, gdy narusza prawo karne czy prawo deliktów chroniące konkurencyjne interesy innych osób. „Dopóki działania pozwanego są informacyjne, perswazyjne czy zabiegające o poparcie dla jego konkretnych poglądów na aborcję, takie działania nie będą ograniczane. Fakt, że (...) zdjęcia [abortowanych płodów] mogą być przez niektórych scharakteryzowane jako niesmaczne czy niepokojące, czy też, że pikietowanie uczyniło innych nerwowymi, zakłopotanymi czy przygnębionymi nie jest podstawą do zakazania czy ograniczenia pikietowania" ${ }^{\prime 0}$.

\footnotetext{
89 Planned Parenthood Regina Inc. v. Whatcott 2002 SKQB 312 (CanLII).

90 Ibidem (16).
} 


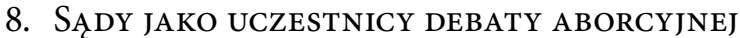

Przebieg sądowych postępowań przeciwko aktywistom pro-life oraz zapadające $w$ ich sprawach wyroki każą podnieść pytanie o bezstronność kanadyjskich sądów. Tytułem egzemplifikacji można wskazać wyrok Sądu Sprawiedliwości Ontario z 21 marca 2012 r. uznający Mary Wagner winną zakłócania korzystania $\mathrm{z}$ kliniki aborcyjnej oraz naruszenia warunków sądowego nadzoru kuratorskiego. Mary Wagner 8 listopada 2011 r. weszła na teren kliniki aborcyjnej w Toronto i przekonywała obecne tam ciężarne kobiety do zmiany decyzji w sprawie aborcji, co u niektórych wywołało zdenerwowanie i płacz. Zdaniem sądu Wagner nie tylko zamierzała zakomunikować swoje poglądy w kwestii aborcji - co zgodnie z art. 430 ust. 7 k.k. wyłączałoby jej odpowiedzialność - ale przeszkadzała pacjentkom i personelowi, którzy chcieli wykonywać zgodną z prawem działalność oraz dążyła do obstrukcji kliniki, utrudniając innym osobom wchodzenie do niej. Skazanej wymierzono karę 6 miesięcy pozbawienia wolności oraz orzeczono wobec niej trzyletni okres próby.

Abstrahując od prawidłowości ustalenia stanu faktycznego sprawy i jego prawnej oceny, można podnieść następujące obiekcje. Po pierwsze, w czasie rozprawy zdenerwowany sędzia zwrócił się do oskarżonej m.in. słowami „Ty się mylisz i twój Bóg się myli!”. Antyaborcyjną aktywność Wagner określił zaś mianem „tchórzliwej”. Sąd odwoławczy co prawda zauważył, że sędzia nie powinien „poddawać spontanicznie oskarżonej przesłuchaniu co do jej rozumienia rządów prawa” oraz że „szereg uwag poczynionych przez sędziego w tej sprawie podczas przesłuchania było nierozważnych i niewłaściwych" ${ }^{91}$, niemniej jednak sędzia nie przejawił jego zdaniem braku stronniczości (bias).

Po drugie, poczyniona w uzasadnieniu orzeczenia charakterystyka oskarżonej i jej aktywności pro-life nasuwa skojarzenia $\mathrm{z}$ brzmieniem niektórych wyroków wydanych w Polsce Ludowej przez sądy przeciwko opozycjonistom. Sąd uznał, iż oskarżona przejawiła „najwyższą pogardę" wobec wcześniejszych sądowych nakazów i zaprezentowała „brak szacunku dla praw innych i rządów prawa”. Kierując się „wyższym

91 R. v. Wagner, 2012 ONSC 5461 (CanLII) (31). 
moralnym obowiązkiem”, a nie prawami naszego państwa, oskarżona przedstawia „potencjalne zagrożenie i niebezpieczeństwo dla pomyślności i bezpieczeństwa społeczeństwa obywatelskiego". W ten sposób zasiała „ziarna bezprawia (...), nieporządku, a być może nawet anarchii”. Zamiast w sposób legalny wyrażać zdanie odrębne czy protestować, „Zdecydowała się krzywdzić niewinnych ludzi”92.

Po trzecie, sąd nie uwzględnił zgodnego wniosku obu stron co do wymiaru kary i skazał oskarżoną na karę maksymalnie możliwą przewidzianą przez prawo, a jednocześnie cztery razy surowszą niż kara orzeczona wobec Wagner za wcześniejszy czyn analogiczny. Sąd odwoławczy zmniejszył karę do 88 dni odbytego już aresztu.

\section{Podsumowanie}

Studium kanadyjskiego orzecznictwa pokazuje, iż liberalnemu ustawodawstwu aborcyjnemu towarzyszy antyliberalne podejście do publicznych protestów pro-life. Działalność aktywistów antyaborcyjnych jest w Kanadzie na różne sposoby reglamentowana w stopniu większym niż w USA czy Europie ${ }^{93}$. Kategoryczny zakaz protestów antyaborcyjnych w sąsiedztwie klinik aborcyjnych - mający umocowanie w ustawie lub w sądowych nakazach - wydaje się być środkiem nieproporcjonalnym do stojących u jego podstaw celów. Zapewnienie bezpiecznego dostępu ciężarnym kobietom do klinik aborcyjnych nie wymaga całkowitego zanegowania wolności słowa działaczy pro-life. Stan rzeczy, w którym osoby pokojowo wyrażające swój sprzeciw przeciwko aborcji na publicznym chodniku przed kliniką aborcyjną ponoszą karę pozbawienia wolności, przeczy „wolnemu i demokratycznemu społeczeństwu”, o którym mowa w art. 1 Kanadyjskiej Karty Praw i Wolności. Wieloletnie przebywanie w zakładzie karnym - jak w przypadku Lindy Gibbons łacznie 10 lat

\footnotetext{
92 Ibidem (17).

93 Por. G. Maroń Konstytucyjna wolność słowa w orzecznictwie sądów USA na przykładzie protestów antyaborcyjnych, «Zeszyty Naukowe Uniwersytetu Rzeszowskiego. Prawo» 16/2015, s. 87-118; IDEM, Prawne standardy debaty aborcyjnej w świetle orzecznictwa strasburskiego, «Forum Prawnicze» 3/2015, s. 47-65.
} 
(sic!) - za pasywną, milczącą obronę życia dzieci poczętych jest świadectwem wysoce selektywnego rozumienia zarówno przez kanadyjski wymiar sprawiedliwości, jak i kanadyjskie społeczeństwo takich pojęć, jak wolność słowa, tolerancja, aksjologiczny pluralizm. Znamienne, iż współcześni kanadyjscy antyaborcyjni więźniowie sumienia, jak Mary Wagner, są znani w Polsce, a niemal zapomniani w swojej ojczyźnie. Tłumienie przez władze publiczne mowy pro-life nie spotkało się nie tylko z krytyką, ale nawet $\mathrm{z}$ zainteresowaniem po stronie kanadyjskiej jurysprudencji czy generalnie u ludzi nauki.

Jedni z nielicznych krytyków tego stanu rzeczy pytają: „Dlaczego pozwalamy, aby niesprawiedliwe prawo było stosowane w Kanadzie przeciwko prawej osobie, pozbawiając ją prawa do pokojowego protestu, a przez uwięzienie, pozbawiając ją wszystkich jej praw naraz? Pozwalamy na to, ponieważ Linda Gibbons i ludzie tacy jak ona kwestionują drogę, jaką nasze państwo obrało, w stopniu dalece większym niż czyni to jakakolwiek z naszych partii politycznych. Zmierzamy w stronę, którą Jan Paweł II określił mianem cywilizacji śmierci, a ona wzywa nas do powrotu do cywilizacji życia. Odrzuciliśmy religie i tradycje, z których się wywodzimy, a ona błaga nas, abyśmy nie byli tak lekkomyślni. Wielu nie zgadza się z nią, w czym nie ma nic złego. Nie konfrontujemy się z nią jednak uczciwie w naszych mediach i naszych sądach. Ukrywamy ją cieleśnie w więzieniu, a jej poglądy są skrywane równie skutecznie medialną ciszą"94.

Argumentacja kanadyjskich sądów, że poza sąsiedztwem klinik aborcyjnych można swobodnie artykułować swoje antyaborcyjne poglądy, jest częściowo nieprawdziwa. Omówione przypadki reglamentacji pokojowych protestów pro-life na terenie publicznych uczelni, portów lotniczych a nawet chodników, ulic i placów dowodzi, iż przestrzeń publiczna pełni rolę „rynku idei” wobec tylko niektórych - tych „postępowych” - poglądów i opinii. Nie zawsze sądy stawały w obronie konstytucyjnych wolności działaczy pro-life pragnących manifestować swoje stanowisko na tradycyjnym forum publicznym. Niepokoją próby pociągania do

94 A. Irvine, J. Russell, In the Agora. The Public Face of Canadian Philosophy, Toronto 2006, s. 269. 
odpowiedzialności zawodowej osób, które w czasie wolnym od pracy i zgodnie z prawem publicznie wyrażają swój sprzeciw wobec aborcji. Kanadyjski wymiar sprawiedliwości potrzebuje koherentności rozstrzygnięć z własnymi autodeklaracjami, tak aby rzeczywiście wolność słowa gwarantowała każdemu możliwość „manifestowania swoich poglądów, opinii, przekonań, w zasadzie wszelkich ekspresji serca i umysłu, bez względu na ich niepopularność, niesmaczność czy sprzeczność z mainstreamem”. Parafrazując tytuł książki znanego amerykańskiego filozofa prawa, Ronalda Dworkina ${ }^{95}$, można apelować do kanadyjskich sądów, ale także tamtejszego ustawodawcy, aby w swej praktyce jurysdykcyjnej i legislacyjnej „brali wolność słowa oraz wolność sumienia i religii poważnie”.

Public Pro-life Protests in Canadian Case Law

\section{Summary}

The article deals with the legal standards applied in public anti-abortion protests in Canada. On the basis of an examination of Canadian case law, the author argues that the restrictions on pro-life protests are disproportionate with respect to the objective of ensuring safe access to women's reproductive rights. The Access to Abortion Services Act and court injunctions are preventing pro-lifers from demonstrating in the vicinity of abortion clinics in defence of the right to life of unborn children. The degree to which pro-lifers' constitutional freedom of speech is being infringed is in breach of the principles of the liberal state. The right to express opposition to abortion is also limited, although to a lesser extent, in other public places, such as street pavements and squares, university campuses and airport terminals. In the author's view, imprisonment as the penalty for peaceful protest against the Canadian abortion law - for example, Linda Gibbons spent a total of over 10 years in prison for her pro-life activities! - is inherently incompatible with the essence of a "free and democratic society" as defined in Article 1 of the Canadian Charter of Rights and Freedoms.

95 R. DwOrkin, Biorąc prawa poważnie, Warszawa 1998. 
Słowa kluczowe: protesty pro-life, aborcja, Kanada, orzecznictwo. Keywords: pro-life protests, abortion, Canada, case law.

\section{Literatura:}

Albert A., Protest, Proportionality, and the Politics of Privacy: Mediating the Tension Between the Right of Access to Abortion Clinics and Free Religious Expression in Canada and the United States, «Loyola Of Los Angeles International and Comparative Law Review» 27.1/2005, s. 1-62

Horwitz P., Anti-Abortion Protests and the Public Forum. A Comment on Ontario (Attorney General) v. Dieleman, «Advocates' Quarterly» 17.3/1995, s. 466-501.

Huscroft G., Reconciling Duty and Discretion: The Attorney General in the Charter Era, «Queen's Law Journal» 34/2009, s. 773-811

Irvine A., Russell J., In the Agora. The Public Face of Canadian Philosophy, Toronto 2006

Jones C., Immunizing Universities from Charter Review: Are We 'Contracting Out' Censorship?, «University of New Brunswick Law Journal» 52/2003, s. 261-276.

Maroń G, Glosa do wyroku Sadu Sprawiedliwości Ontario w sprawie R. v. Wagner $z$ dnia 12.06.2014 (R. v. Wagner, 2015 ONCJ 66), «Roczniki Nauk Prawnych» 3/2015, s. 193-216

MAROŃ G., Konstytucyjna wolność słowa w orzecznictwie sądów USA na przykładzie protestów antyaborcyjnych, «Zeszyty Naukowe Uniwersytetu Rzeszowskiego. Prawo»16/2015, s. 87-118

Maroń G., Prawne standardy debaty aborcyjnej w świetle orzecznictwa strasburskiego, «Forum Prawnicze» 3/2015, s. 47-65

Mix-Ross D., Exploring the Charter's Horizons: Universities, Free Speech, and the Role of Constitutional Rights in Private Legal Relations, Toronto 2009, s. 1-3

Saurette P., Gordon K., Arguing Abortion: The New Anti-Abortion Discourse in Canada, "Canadian Journal of Political Science» 46.1/2013, s. 157-185

Silletta F., Revisiting Charter Application to Universities, «Appeal - Review of Current Law and Law Reform» 20/2015, s. 79-98

Waldron M., Free to Believe: Rethinking Freedom of Conscience and Religion in Canada, Toronto 2013. 